\title{
Jubileusz 50-lecia środowiska filologicznego Uniwersytetu w Białymstoku: 1968-2018, Białystok, 9 czerwca 2018 roku.
}

\section{Sprawozdanie}

1.

W 1968 roku utworzono w Białymstoku Wyższą Szkołę Nauczycielską, od samego początku ściśle powiązaną ze środowiskiem Uniwersytetu Warszawskiego ${ }^{1}$. Funkcjonująca przez lata jako Filia UW, w roku 1997 stała się samodzielnym Uniwersytetem w Białymstoku. Równo pięćdziesiąt lat temu zaczął się burzliwy rozwój dwóch środowisk humanistycznych: filologicznego i historycznego, które do 1999 roku działały we wspólnym Wydziale Humanistycznym, podzielonym w końcu na Wydział Historyczno-Socjologiczny i Wydział Filologiczny. W roku 2018

Daniel Karczewski - dr, językoznawca; anglista; Prodziekan ds. Nauki Wydziału Filologicznego Uniwersytetu w Białymstoku.

* Jarosław Ławski - prof. zw. dr hab., literaturoznawca; kierownik Katedry Badań Filologicznych „Wschód - Zachód” na Wydziale Filologicznym Uniwersytetu w Białymstoku; Dziekan Wydziału Filologicznego UwB.

1 Zob. Uniwersytet $w$ Biatymstoku in statu nascendi (1968-1997), wybór i opr. J. E. Dąbrowska, Białystok 2015; X lat Uniwersytetu $w$ Biatymstoku (1997-2007), red. J. Nikitorowicz et al., Białystok 2008; Uniwersytet Warszawski. Filia w Białymstoku 1968-1978, opr. B. Noworolska, Białystok 1978 oraz Uniwersytet w Biatymstoku: 2008-2017, red. R. Ciborowski et al., Białystok 2017. 
przypadł więc jubileusz półwiecza obu środowisk naukowych: filologicznego i historycznego ${ }^{2}$.

Dnia 9 czerwca 2018 roku w Auli Wydziału Filologicznego Uniwersytetu w Białymstoku odbyły się uroczyste obchody 50. rocznicy powstania środowiska filologicznego. Była to kulminacja obrad, które zapoczątkowała językoznawcza konferencja neofilologiczna w grudniu 2017 roku $^{3}$, a zakończyło w grudniu 2018 roku nadanie imienia prof. Anny Miatluk sali, gdzie mieści się Czytelnia Neofilologiczna. Jednym z kluczowych momentów Jubileuszu była uroczystość nadania doktoratów honoris causa Uniwersytetu w Białymstoku prof. Alinie Kowalczykowej (IBL PAN) oraz prof. Halinie Krukowskiej (UwB), która odbyła się 17 kwietnia 2018 roku4

W centrum wydarzeń, odbywających się 9 czerwca, znalazła się uroczystość w Auli zatytułowana „Środowiska Filologiczne wczoraj, dziś i jutro. Otwarcie Jubileuszu”. Otworzył ją przemówieniem Dziekan Wydziału Filologicznego, prof. zw. Jarosław Ławski, który podkreślił, iż pięćdziesiąt lat rozwoju Białostockiego Środowiska Filologicznego należy uznać za niewątpliwy, acz z wielu powodów zaskakujący sukces. Jak podkreślił mówca, środowisko to rozwinęło się niemal „od zera” w Polsce północnowschodniej, gdzie po II wojnie światowej pracowało tylko dwóch filologów ze stopniami naukowymi doktora. Zdaniem prof. Ławskiego, swój sukces filolodzy dzielą wspólnie z historykami, filozofami i socjologami, z którymi przez lata tworzyli wspólnotę Wydziału Humanistycznego.

Dziekan powitał uroczyście Gości, wśród których znaleźli się: Prorektor UwB ds. Nauki, prof. Izabela Święcicka, Dziekan Wydziału Biologiczno-Chemicznego, prof. Beata Godlewska-Żyłkiewicz, Dziekan Wydziału

2 Zob. publikacje upamiętniające te jubileusze: Białostockie środowisko filologiczne: 1968-2018. Historia w 45 wywiadach, rozmawiał D. Sołowiej, idea, wstęp, red. J. Ławski, Białystok 2018 oraz Pótwiecze. Studia historyczne w Białymstoku 1968-2018, red. A. Cz. Dobroński, G. Zackiewicz, Białystok 2018.

3 Była to sesja: "The 1st Białystok Conference on Theoretical and Applied Linguistics", Institute of Modern Languages, University of Białystok, 7-8 December 2017. W otwarciu Konferencji wziął udział JM Rektor Uniwersytetu w Białymstoku, prof. Robert Ciborowski.

4 Profesor Alina Kowalczykowa. Doktor honoris causa Uniwersytetu w Biatymstoku, red. J. Godlewska, A. Janicka, J. Ławski, Białystok 2018 oraz Profesor Halina Krukowska. Doktor honoris causa Uniwersytetu w Biatymstoku, red. jw., Białystok 2018. 


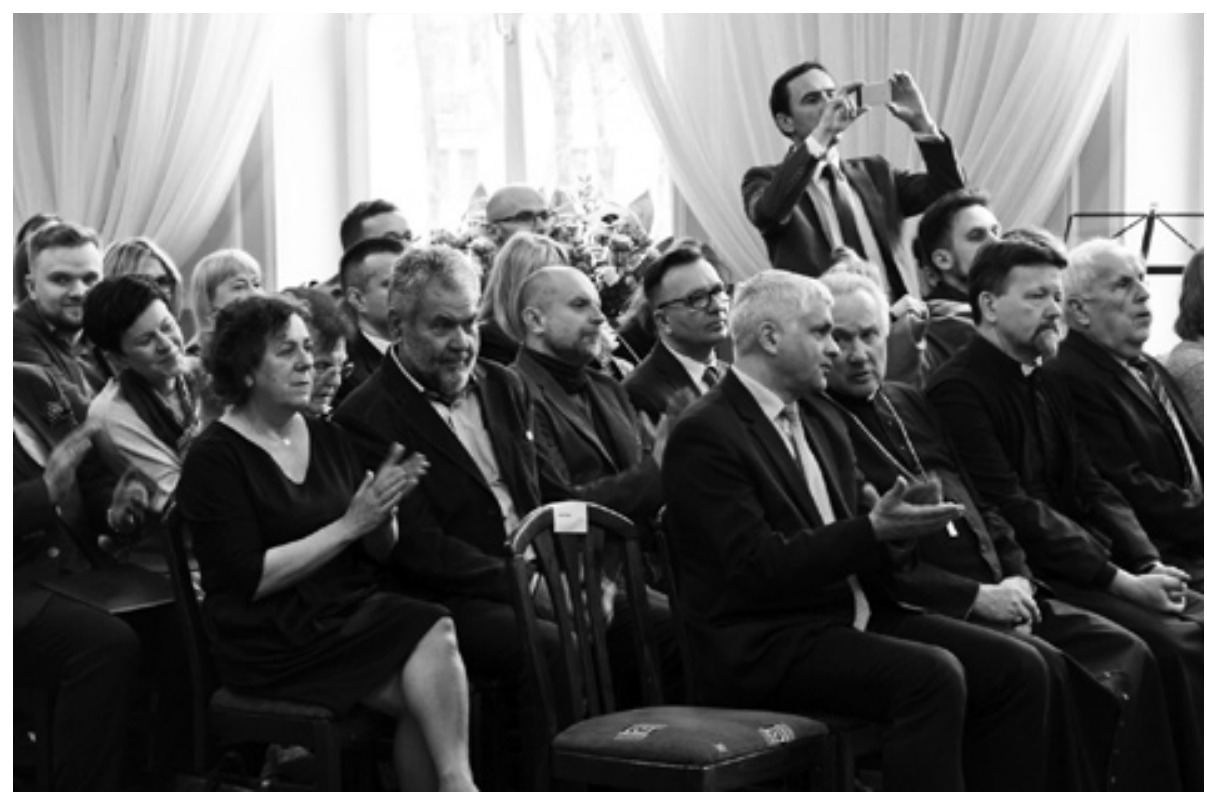

Uroczystość wręczenia doktoratów honoris causa prof. Halinie Krukowskiej i prof. Alinie Kowalczykowej; fot. Emilian Aksiucik; źródło: http://uwb.edu.pl

Historyczno-Socjologicznego, prof. Joanna Sadowska, Prodziekan Wydziału Ekonomii i Zarządzania, prof. Grażyna Michalczuk, Pełnomocnik Wojewody Podlaskiego Bohdana Paszkowskiego, pan Aleksander Orłowski, Dyrektor Instytutu Historii, prof. Jan Snopko, Dyr. Książnicy Podlaskiej im. Łukasza Górnickiego, Jolanta Gadek, Kierownik Działu Naukowego Książnicy Podlaskiej, dr Łukasz Zabielski, była Dyr. Biblioteki Uniwersyteckiej im. Jerzego Giedroycia, mgr Barbara Brzezińska-Stec, Burmistrz Wasilkowa, Mirosław Bielawski, wieloletni Dziekan Wydziału Filologicznego, prof. Bogusław Nowowiejski, jak również: prof. Urszula Sokólska (dyr. IFP), prof. Halina Parafianowicz, prof. Cezary Kuklo, prof. Andrzej Kondratiuk i wielu, wielu innych. Licznie stawili się emerytowani pracownicy Wydziału, by wymienić tylko prof. Piotra Wróblewskiego, dr Bożenę Chodźko, dr. Wacława Szerszunowicza, prof. Jadwigę Sadowską, prof. Romana Hajczuka, dr. Mikołaja Kruka. Nie zabrakło znanych i wypróbowanych Przyjaciół środowiska filologicznego. Na sali byli: pani Anna Worowska, pani Lucy Lisowska, pani Aleksandra Nowacka, państwo Grażyna i Ireneusz Dawidowiczowie. 
W wypełnionej po brzegi sali przemawiali po kolei:

- Prof. Izabela Święcicka, która odczytała list od JM Rektora UwB, prof. Roberta Ciborowskiego;

- Prodziekan Wydziału Filologicznego UwB, dr Daniel Karczewski;

- Prof. Violetta Wejs-Milewska, dyr. Instytutu Filologii Polskiej;

- Prof. Leonarda Dacewicz, dyr. Instytutu Filologii Wschodniosłowiańskiej;

- Prof. Jerzy Kamionowski, dyr. Instytutu Neofilologii;

- Prof. Alicja Kisielewska, dyr. Międzywydziałowego Instytutu Kulturoznawstwa i Sztuki.

Kierownicy poszczególnych jednostek zaprezentowali krótko dorobek Instytutów. Prof. Kisielewska przedstawiła dodatkowo - bardzo udany - film na temat studiów kulturoznawczych ${ }^{5}$. Na samym już początku uroczystości wyświetlono interesujący, 10-minutowy film mgr. Karola Więcha, pokazujący w najwyższym skrócie minione 50 lat środowiska filologicznego, zawierający między innymi wspomnienia pracowników Wydziału: Wandy Supy, Krzysztofa Bogackiego, Krystyny Jakowskiej, Jolanty Sztachelskiej, Sławomira Raubego.

\section{2.}

Po części przemówieniowej zainaugurowano mniej oficjalną część, w czasie której wspominano minione półwiecze. Prof. Halina Krukowska przypomniała, iż praca w czasach PRL-u wiązała się z codzienną kontrolą, cenzurą, nadzorem PZPR nad tym, co się mówi na zajęciach, także z donosicielstwem. Podkreśliła przy tym, iż w żadnym wypadku nie wpływało to na jej zaangażowanie w pracę ze studentami. Prof. Violetta Wejs-Milewska, oddając cześć pracownikom Uniwersytetu Warszawskiego, zaangażowanym w tworzenie białostockiej Filii UW, zaakcentowała znaczenia białostockiej atmosfery, podkreśliła entuzjazm oraz wysoki poziom uczniów, studentów i rolę naukowców wywodzących się z Pod-

5 Film przygotował mgr Karol Więch. Wystąpił w nim - w roli narratora - między innymi prof. Sławomir Raube. 
lasia. Prof. Cezary Kuklo, historyk, z nostalgią wspominał czasy, gdy historycy i poloniści jeździli na wspólne obozy naukowe. Prof. Jolanta Sztachelska zaproponowała, by minutą ciszy uczcić nieżyjących już Kolegów z Wydziału, m.in. prof. Zbigniewa Jarosińskiego, dr Marię Koszycką, dra Zbigniewa Suszczyńskiego, prof. Heleną Karwacką. Dr Urszula Andrejewicz podkreśliła z kolei rolę prof. Zygmunta Saloniego w formowaniu się środowiska białostockich językoznawców. Prof. Beata Godlewska-Żyłkiewicz przywołała w wystąpieniu fragmenty wspomnień naukowców warszawskich, wysoko oceniających pracę swych białostockich kolegów. Prof. Ewa Paczoska, literaturoznawczyni z Uniwersytetu Warszawskiego, która przepracowała w Białymstoku kilkanaście lat, przypomniała niezwykle twórczą atmosferę lat 80. i 90. w białostockim środowisku.

Wielu uczestników uroczystości wskazywało często tego dnia, iż liczni pracownicy lub absolwenci Filii UW i Uniwersytetu w Białymstoku pełnią dziś ważną rolę w naukowym i kulturalnym życiu kraju, by wymienić: prof. Barbarę Bobrowską, polonistkę (UKSW, Warszawa), prof. Lucynę Aleksandrowicz-Pędich (SWPS, Warszawa), dyr. Jolantę Gadek (Książnica Podlaska im. Ł. Górnickiego), dr hab. Urszulę Kowalczuk (UW, Warszawa), prof. Dorotę Kielak (UKSW, Warszawa), dr hab. Joannę Zajkowską (UKSW, Warszawa), dr hab. Mariana Płacheckiego, prof. SWPS (Warszawa).

Uroczystą akademię brawurowo poprowadzili studenci Wydziału Filologicznego: Katarzyna Kołaczyk (kulturoznawstwo) i Adrian Baranowski (polonistyka). Nad medialną stroną wydarzenia czuwali: rzecznik prasowa UwB Katarzyna Dziedzik i red. Dominik Sołowiej. Na zakończenie zaproszono wszystkich obecnych na lampkę szampana w hallu Wydziału Filologicznego. W czasie, gdy Goście raczyli się kawą, słodyczami i szampanem, można też było obejrzeć wystawę kilkudziesięciu (ponad 80) tomów publikacji napisanych przez białostockich filologów. Ponadto każdy zainteresowany mógł za darmo otrzymać jedną z publikacji, które organizatorzy przygotowali na tę okazję (rozdano ponad dwieście tomów różnych prac). Gdy odbywała się akademia, na ulicach Białegostoku dało się spotkać studentów filologii rozdających białostoczanom specjalnie dobrane, dowcipne wiersze poetów polskich i obcych. Akcja ta zakończyła się nadspodziewanym sukcesem! 


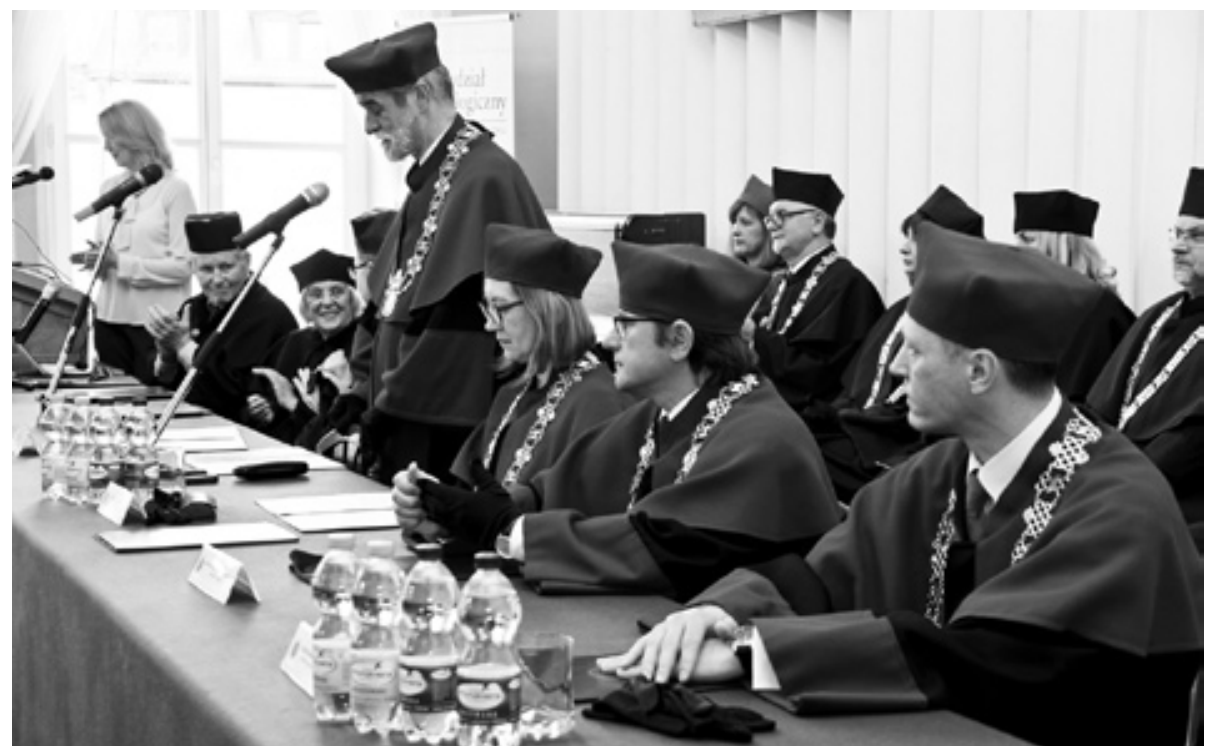

Uroczystość wręczenia doktoratów honoris causa prof. Halinie Krukowskiej i prof. Alinie Kowalczykowej na Wydziale Filologicznym UwB; przemawia: dr hab. Jerzy Halicki, prof. UwB; fot. Emilian Aksiucik; źródło: http://uwb.edu.pl

Warto podkreślić obecność przedstawicieli mediów na uroczystości: TVP Białystok, Radia Białystok, Radia „Racja”, białostockich gazet, które - jak „Kurier Poranny” - sprawowały patronat medialny. Całość obchodów objęli Patronatem Honorowym: Prezydent Miasta Białegostoku dr hab. Tadeusz Truskolaski i JM Rektor Uniwersytetu w Białymstoku, prof. Robert Ciborowski.

Po skróconej nieco przerwie na lampkę szampana (godz. 13.00) ${ }^{6}$ zaproponowano gościom wysłuchanie krótkiego koncertu Kwartetu Dworskiego. Przedstawił on współczesne interpretacje piosenek Kabaretu Starszych Panów ${ }^{7}$. Zaraz potem (godz. 14.00) zaproszono obecnych na spotkanie z prof. Haliną Krukowską oraz prof. Aliną Kowalczykową, doktorami honoris causa UwB. godziny.

6 Pierwsza część uroczystości z powodu licznych głosów gości przedłużyła się o pół

7 Występ zespołu oceniono jako poprawny. O wiele większy aplauz zyskał jednak występ zespołu „Non Terminus” dnia 17 kwietnia 2018 roku w czasie uroczystości wręczenia doktoratów honoris causa. 
Prof. Kowalczykowa podkreśliła ważną rolę, jaką zawsze w kulturze polskiej odgrywał Białystok, położony między Warszawą, Grodnem a Wilnem. Z ośrodkami tymi związany był całym swym życiem Jej Ojciec, prof. Stanisław Lorentz, długoletni dyrektor Muzeum Narodowego ${ }^{8}$. Prof. Kowalczykowa podkreśliła, iż nadużyciem jest używanie słowa „prowincja” w odniesieniu do wschodnich ziem Rzeczypospolitej. Krytycznie odniosła się również do „oficjalnej”, „upolitycznionej” wersji historii przekazywanej we współczesnej szkole. Poparła też protesty naukowców, w tym środowiska białostockiego, przeciwko nowej ustawie o szkolnictwie wyższym lansowanej przez ministra Jarosława Gowina.

Z kolei prof. Krukowska zaakcentowała rolę takich ośrodków jak Białystok w kształtowaniu postaw współczesnych Polaków. Podkreśliła, że nie można myśleć o rozwoju nowoczesnego społeczeństwa bez rozkwitu edukacji i badań humanistycznych ${ }^{9}$. Spotkanie poprowadzili redaktor Dorota Sokołowska (Polskie Radio Białystok) i dr Krzysztof Korotkich (Katedra Badań Filologicznych „Wschód - Zachód” UwB).

Ostatnim akcentem obchodów odbywających się na Wydziale Filologicznym była promocja okolicznościowego tomu Białostockie środowisko filologiczne 1968-2018. Historia w 45 wywiadach (rozmowy przeprowadził Dominik Sołowiej, idea, wstęp i redakcja Jarosław Ławski, Białystok, Alter Studio, 2018, ss. 523). Rozmowę o tomie zawierającym wywiady z 45 postaciami filologów i historyków, filozofów i bibliotekoznawców, tworzących środowisko u jego początków, prowadzili red. Dominik Sołowiej oraz prof. Marek Kochanowski, zaś w roli rozmówców wystąpili prof. Ewa Paczoska (UW, Warszawa) i prof. Violetta Wejs-Milewska (UwB). W trakcie spotkania głos zabrali dr Barbara Głowacka (romanistka, UwB), prof. Lucyna Aleksandrowicz-Pędich (anglistka, SWPS) i prof. Jarosław Ławski (UwB). Ten ostatni zdecydo-

8 Zob. A. Kowalczykowa, Konserwator Stanistaw Lorentz $w$ Wilnie; Album Stanisława Lorentza, [w:] tejże, Wobec współczesności. Tematy poważne i mniej serio, red. nauk. i opr. tekstu A. Janicka, G. Kowalski, Pisma rozproszone i zarzucone, T. II, Białystok 2016.

9 Zob. Humanistka. Z prof. Halina Krukowska rozmawia Jerzy Szerszunowicz, „Kurier Poranny. Magazyn”, 19 października 2007 oraz H. Krukowska, „Pan Tadeusz” jako poezja czysta. Studia i szkice o Mickiewiczu, Białystok 2016. 
wanie podkreślił, iż ukaże się także drugi tom wywiadów, zawierający rozmowy z drugim pokoleniem pracowników Wydziału Filologicznego, którzy zdobywali doktoraty i habilitacje po 1989 roku. Z wypowiedzi prof. Paczoskiej i prof. Wejs-Milewskiej wynikało też, iż pamięć tych samych wydarzeń z teraźniejszości i przeszłości poddana może być zupełnie odmiennym interpretacjom, a pomimo tego nie tracą one nic ze swego nostalgicznego czaru.

Rozpoczęte o 11.00 uroczystości zakończyły się o 15.30. Ich ostatnim, już nieoficjalnym, akcentem był Bal Absolwenta w Restauracji „Camelot”. 50-lecie środowiska świętowało tu od godz. 19.00 do 1.30 w nocy ponad pięćdziesięciu absolwentów i pracowników Wydziału Filologicznego. Rozmawiano, wznoszono toasty i tańczono bez przerwy przez ponad sześć godzin. Zdaniem uczestników, Bal był wydarzeniem znakomitym, takim, które integruje społeczność Wydziału. Zaproponowano - bynajmniej nie żartobliwie - by organizować podobne imprezy cyklicznie.

3.

Organizacja tak dużej imprezy nie byłaby możliwa bez zaangażowania dużej grupy pracowników i studentów Wydziału, którzy od końca 2017 ją roku przygotowywali. Pracę Komitetu Organizacyjnego koordynowała na co dzień - i trzeba podkreślić: z finalnym sukcesem! mgr Ewa Gorlewska, językoznawczyni, współpracująca z zaangażowanymi w te wysiłki innymi pracownikami: dr hab. Marzanną Karolczuk, dr Ewą Lewicką-Mroczek, dr Edytą Wajdą, dr Jolantą Chomko, dr Maryną Michaluk, dr Sarą Moroz, dr Karoliną Wierel, mgr. Karolem Więchem, dr Katarzyną Sokołowską, dr. Mariuszem Lesiem, dr Elżbietą Jurkowską, mgr Joanną Godlewską, mgr. Jarosławem Kuźmickim i dr. Krzysztofem Korotkichem. Ich działania wspierali: prof. Leonarda Dacewicz, prof. Alicja Kisielewska, prof. Violetta Wejs-Milewska, prodziekan dr Robert Szymula, prof. Jerzy Kamionowski, prof. Kamila Budrowska, dyr. Bożena Poniatowicz i koordynujący całość prof. Jarosław Ławski. Organizatorzy przygotowali, co warto podkreślić, specjalne zaproszenia, jubileuszowe 
zapinki, komplety wierszy rozdawane białostoczanom. Zapewnili też uroczystościom szeroki rozgłos medialny ${ }^{10}$.

Wolno na koniec zauważyć, iż w tej samej Auli kilka dni później swój Jubileusz, również z udziałem delegacji filologów, świętowali białostoccy historycy.

Uroczystości podsumowały 50-letni, burzliwy, ale zwieńczony sukcesem, okres rozwoju filologii w północno-wschodniej Polsce i w Białymstoku. Odbywały się jednak w atmosferze napięć i protestów towarzyszących uchwalaniu nowej ustawy o nauce, w świetle której los mniejszych środowisk humanistycznych jawił się nader niepewnie. Należy mieć nadzieję, iż środowisko filologów białostockich, skupiające ponad czterdziestu tylko profesorów i doktorów habilitowanych, przetrwa i te „zmiany”, te „reformy”. Tak jak przetrwało wszystkie podobne działania po 1968 i po 1989 roku.

Jako Aneksy do niniejszego Sprawozdania publikujemy wystąpienia wygłoszone w czasie uroczystości 9 czerwca 2018 roku.

10 Zob. 50 lat uniwersyteckiej humanistyki w Biatymstoku, „Wrota Podlasia”; D. Sokołowska, Środowisko filologiczne z Białegostoku świętuje 50-lecie, Polskie Radio Białystok; Prof. Violetta Wejs-Milewska: „50 lat to dobry wiek...”, Polskie Radio Białystok; Aktualności: Pót wieku filologów, TVP 3 Białystok; A. Sawczenko, Białostockie środowisko filologiczne 1968-2018, czyli rozmowy nie tylko o literaturze, „Kurier Poranny” 14.16 .2018 oraz Z Dominikiem Sołowiejem rozmawia Dorota Sokołowska: „Z okazji jubileuszu filolodzy...”, PR Białystok 10.06.2018. 


\author{
ANEKS nr 1 \\ Jarosław Ławski \\ Wydział Filologiczny \\ Uniwersytetu w Białymstoku
}

\title{
OSTATNIE TAKIE PIĘĆDZIESIĄT LAT
}

\author{
Przemówienie Dziekana Wydziału Filologicznego \\ w czasie Jubileuszu 9 czerwca 2018 roku
}

\section{Wielce Szanowni Państwo!}

Chcę wszystkich Państwa gorąco powitać na Jubileuszu, tak dla nas ważnym, Białostockiego Środowiska Filologicznego!

Minęło 50 lat!

Gdzieś późną wiosną 1968 roku wszystko musiało być już postanowione: że tu, w Białymstoku, ruszą studia filologiczno-historyczne pod egidą, pieczą naukową Uniwersytetu Warszawskiego. Pierwsi studenci już stąd, z Podlasia i Białegostoku, szykowali się do zajęć, trwało kompletowanie kadry wykładowców, przede wszystkim tej z Warszawy i innych ośrodków, ale i pierwszych „miejscowych” ochotników nauki, jak dziś ich nazwę...

Od samego początku, co trzeba tego dnia z całą mocą podkreślić, środowisko naukowe filologów i historyków, które wtedy się rodziło, powstawało pod naukową opieką środowiska badawczego Uniwersytetu Warszawskiego i proces narodzin białostockiej humanistyki dokonywał się z jego ogromnym udziałem (czasem też z entuzjazmem). Studia wyższe - rzecz nowa wtedy w Polsce Północno-Wschodniej - przyciągały studentów i chętnych do pracy w nauce. To naturalne - nigdy wcześniej nie było na tych ziemiach studiów wyższych o profilu humanistycznym... Tak zaczynało powstawać Środowisko.

Już 15 października 1968 roku immatrykulowano dwoje pierwszych studentów. Indeksy nr 1 i nr 2 otrzymali: pani Elżbieta Sikorska-Nowak (późniejsza wieloletnia wykładowczyni językoznawstwa na polonistyce) 
i pan Józef Maroszek (dr, dziś znany profesor historii, znakomity znawca regionu).

Jakże inny był wtedy Białystok! Tę jego inność - wiejskość, ruralność, rustykalność, powojenność, jakkolwiek to nazwiemy - to niepodobieństwo do dzisiejszego miasta Anno Domini 2018, nawet ja, przybyły tu na stałe w 1987 roku, dzielący ledwie trzydzieści jeden lat z pięćdziesięcioletniej historii Środowiska, najpierw jako student polonistyki, a potem pracownik - dostrzegam w całej jaskrawości. Było to inne miasto, jeszcze przed fazą szybkiego rozwoju, miasto, w którym quasi-modernistyczne blokowiska mieszały się z resztą zabudowy drewnianej. Jednych on urzekał, innych nieco, jak mnie w 1987 roku, przerażał. Ale na pewno był inny.

Trzeba powiedzieć, że Wyższa Szkoła Nauczycielska, a potem Filia Uniwersytetu Warszawskiego powstały w czasie - gdy spojrzeć na ów fakt z szerszej perspektywy - nieszczególnym, marnym: było to po Marcu '68, po represjach na uczelniach, po przymusowych wyjazdach obywateli polskich żydowskiego pochodzenia. Na świecie rozgrywała się Praska Wiosna (wraz ze swym dramatycznym kresem w postaci najazdu wojsk Układu Warszawskiego na Czechosłowację). Toczyły się wojny wietnamska i bliskowschodnia. Powoli nadciągało przesilenie polityczne Grudnia '70 roku w Polsce, na Wybrzeżu.

A tu, na obrzeżach świata Zachodu, powstawało - prawie z niczego - środowisko filologiczne, naukowe. Jak zaświadczają liczni świadkowie, po II wojnie światowej było - nie licząc osób przyjezdnych - na północnym-wschodzie Polski położonej w nowych granicach pojałtańskich dwóch doktorów nauk humanistycznych... Do tego trochę magistrów i przede wszystkim nauczyciele z bardzo różnym stopniem edukacji po uczelniach w Warszawie, Gdańsku, Lublinie, Krakowie. Ów stan „zero” nauk humanistycznych na Podlasiu, Suwalszczyźnie i w Łomżyńskiem nie był więc metaforą, stanowił dojmującą z dzisiejszej perspektywy rzeczywistość, lukę. Lecz wtedy mało kto zdawał sobie sprawę z konieczności rozwijania edukacji uniwersyteckiej na ziemiach, które po stalinowskich aneksjach terytoriów, deportacjach ludności i przesunięciach granic tworzyły nowe państwa. Co znaczyło: były białą plamą do zagospodarowania naukowego i edukacyjnego. Mało kto to wiedział, a jeszcze mniej osób działało, by to zmienić. Tym większa chwała pionierom 
i wizjonerom działającym w tak skrajnie niekorzystnych i nieprzejrzystych warunkach politycznych i społecznych...

Dziś tylko nas filologów jest więcej, znacznie więcej - to 120 uczonych, wykładowców, lektorów, w tym ponad 40 samodzielnych pracowników naukowych: doktorów habilitowanych, profesorów uniwersyteckich i tytularnych. A trzeba tu dodać i potencjał naukowy oraz kadrowy Wydziału Historyczno-Socjologicznego. Pięćdziesiąt lat temu były, powtórzę, dwie osoby... Nie ma potrzeby opowiadania historii Środowiska - znajdą ją Państwo w książce, która dziś ma swą premierę: Białostockie środowisko filologiczne: 1968-2018. Historia w 45 wywiadach (rozmowy prowadził Dominik Sołowiej, idea i redakcja niżej podpisanego, Białystok 2018).

Spójrzmy na współczesność - przemijającą w okamgnieniu. Z tamtej epoki końca lat 60. i 70. zostało niewiele - na pewno ten budynek (najpierw przy ul. Liniarskiego, potem na Pl. Uniwersyteckim, a dziś przy Pl. NZS-u 1), wtedy gmach KW PZPR, dziś po prostu siedziba dwóch wydziałów: Historyczno-Socjologicznego i Filologicznego. Gmach KW, zdobyty przez strajkujących studentów w '89 roku, a jakże inny od tego - już mitycznego - budynku przy ul. Świerkowej, gdzie rozpoczynała się i działa od 1968 do 1989 roku wspólna historia filologów, historyków, pedagogów. Pozostała po tym okresie pamięć setek i tysięcy studentów, dziś Gmach Partii występuje w nowej roli, a na Świerkowej rozbudowuje się Wydział Pedagogiki i Psychologii, opodal którego w 2018 roku rozpoczął pracę nowy Rektorat jeszcze/wciąż samodzielnego Uniwersytetu w Białymstoku (znów mówiono tego lata wiele o łączeniu UwB z Politechniką Białostocką) $)^{11}$.

Pozostali w byłym gmachu KW nasi, filologów - można rzec, odwieczni - przyjaciele, sąsiedzi i koledzy: historycy, z którymi przez pół wieku dzieliliśmy losy, przestrzeń, z którymi przez lata (1977-1998) byliśmy we wspólnym Wydziale Humanistycznym. Pamięć o tej wspólnocie losu, nauki i przyjaźni historyków oraz filologów, jest u nas, na Wydziale Filologicznym, dobra i wdzięczna.

11 W końcu widmo łączenia UwB i Politechniki oddaliło się już we wrześniu 2018 roku (dopisek z 24.12.2018). 
Dziś chcemy im za te wspólne pięćdziesiąt lat podziękować! Dziękując, powinniśmy powiedzieć, że i oni okazali niemało cierpliwości do nie tak zawsze jak dziejopisarze uporządkowanych filologów, ludzi o artystyczno-pisarskich duszach...

Podziękowania - szczere i gorące - należą się tym wszystkim, którzy tę opowieść o filologii tworzyli - Koleżankom i Kolegom z Uniwersytetu Warszawskiego przede wszystkim. Przez lata nadającym wysoki naukowy poziom badaniom tu prowadzonym, kształtującym w nowoczesnym kierunku młodą, miejscową kadrę naukową, poświęcającym się nauczaniu studentów, którym do lat 90. trzeba było nierzadko ze stolicy przywozić prace naukowe, teksty, artykuły. Trzeba podziękować też Przyjaciołom z innych ośrodków naukowych, którzy obecnie rozproszeni po kraju kreowali przez lata to Środowisko; dziś pracują lub pracowali w IBL PAN, SWPS, UKSW, ChAT, UWr, UJ, IS PAN, by wspomnieć wybrane uczelnie i jednostki.

Pragnę podziękować wszystkim Koleżankom i Kolegom z Białegostoku, Podlasia, całego północno-wschodniego regionu, którzy budowali to Środowisko, nauczali tysiące studentów, przechodzili szczeble kariery uniwersyteckiej, tworzyli lokalną i ogólnopolską kulturę, literaturę, krytykę, sztukę tu, w Białymstoku, a nie gdzie indziej. Wiem, jaki to był wysiłek! Urodzony w sierpniu '68 roku, pochodzący z Ełku i Mazur, tak jak wielu moich kolegów, doskonale rozumiem teraz, jak niełatwa była to droga. Równolatek Środowiska, powinienem tu, co czynię z przyjemnością, powiedzieć, jak wiele zawdzięczam studiom na białostockiej polonistyce (jeszcze na Filii UW), jak znakomita, wtedy już białostocko-warszawska, a nie tylko warszawsko-białostocka, kadra nauczała nas w tych przełomowych latach 1987-1992. To były studia, mówię to z pełną odpowiedzialnością, które pamięta się przez całe życie: przede wszystkim wykładowców, potem atmosferę udziału w czymś poważnym, a nawet ekskluzywnym i podniosłym, bo tak wtedy odbieraliśmy bycie studentami, a na końcu atmosferę historycznego przełomu, końca PRL-u i początków wolnej Rzeczypospolitej. Tego wszystkiego nie byłoby bez znakomitej białostockiej i warszawskiej kadry, której z serca dziękuję! Dystans i upływający czas jeszcze uwyraźniają znaczenie Białostockiego Środowiska Filologicznego. 
Rzadko cenimy to, co oczywiste. Chciałbym zauważyć, dziękując obecnym i dawnym władzom uczelni, iż raczej nikomu przez te pięćdziesiąt lat nie przyszło do głowy, by filologię i historię zamknąć, by tworzyć tu uniwersytet „branżowy”, na przykład akademię prawniczo-ekonomiczną. Stoimy dziś w przededniu zjawisk, które każą przewartościować dawniejszą pewność, że nic złego stać nam się nie może: trwa wymuszane łączenie uczelni, słychać nagonki przeciw humanistyce (jakoby nieprzydatnej w państwie i bujającej w obłokach rozkwitu gospodarki), zaznajemy „reformy” kolejnego ministra.

Mam nadzieję, że 9 czerwca 2018 roku zakończymy tylko pierwsze, ale nie ostatnie półwiecze obu Środowisk: filologicznego i historycznego. Nadzieja nie oznacza, niestety, w tym przypadku pewności. Póki trwa święto, póty cieszmy się.

W tej chwili chcę też powiedzieć, a i nie sposób tego nie uczynić..., o studentach i absolwentach uczelni - filologach, historykach i innych humanistach. To byli najpierw nauczyciele - ci, którzy wychowali i wychowują dziesiątki tysięcy naszych dzieci z tego i z innych regionów kraju. To byli potem i są dziś przedstawiciele wolnych zawodów - dziennikarze, pisarze, artyści. To będą - ostatnio nader często - biznesmeni, menedżerowie, kupcy, ludzie polityki i władzy (signum temporis: polonista u władzy, historyk dyrektorem...). Jestem pewien, że myślimy dziś o nich z wdzięcznością, a oni w przeważającej większości zachowali o nas dobrą pamięć. Wzajem mamy sobie za co dziękować. Przez lata myśmy patrzyli na nich, przyglądając się temu, jak zmieniają się kolejne pokolenia studentek i studentów, a oni wpatrywali się w nas: czasem z fascynacją, czasem z uśmiechem, dostrzegając, jak się zmieniamy, jak dojrzewamy jako Środowisko.

(Dojrzeli w końcu tak bardzo, że to oni, studenci-organizatorzy tej uroczystości, dali mi tylko 5 minut na przemówienie, żebym „nie przynudzał"...).

Patrząc na minione półwiecze, odnoszę wrażenie (również, co dziwne, nasila się ono tej wiosny), że losy n a s ze go - bo mogę tak powiedzieć do obecnych na sali badaczy i absolwentów z Białegostoku, ale i z Warszawy - że zatem losy naszego Środowiska są sumą wyborów, częściej na szczęście lepszych niż gorszych, sumą decyzji ludzi nim kierujących, decy- 
zji zapewne najczęściej szlachetnie motywowanych, a także, co uważam za kluczowe, sumą i wynikiem wzajemnej, głęboko pojętej, wewnętrznej lojalności wobec siebie i instytucji, jaką była i jest Uczelnia.

Jestem przekonany, że w tych losach ma swój udział duch humanistycznej niezgody na wszystko, co narzucane z zewnątrz. Niezależnie od czasów, nie chcemy być przedmiotem czyichś rachub, koncepcji politycznych i manipulacji. Jest też w nas, humanistach, niewolne od idealizmu, marzenie o wspólnocie, w której w spokoju i bez obsesyjnie ponawianych pseudoreform można badać, interpretować, wyrażać każdy pogląd, a nie tylko ten tak czy inaczej „słuszny”. Marzymy wciąż o uniwersytecie jako republice wolnych duchów, samorządnej, niezależnej, prawdziwie wolnej i roztropnej. A nie o uniwersytecie jako korporacji, firmie zarządzanej przez menadżerów i tak dalej (dziś, jak mało kiedy, wszyscy wiemy i chcemy powiedzieć, czego tak naprawdę nie chcemy!).

Ale - czy kiedykolwiek tu, w Europie Środkowo-Wschodniej, były dobre czasy dla nauki? Był spokój? Może właśnie dlatego jesteśmy humanistami, by się temu opierać. Zapewne wiedzą o tym naszym usposobieniu w duchu niezgody ci wszyscy piewcy postępu, którzy nas szczerze nie cierpią. Lecz czy ktokolwiek - partia albo człowiek, polityk czy lub inny - wygrał kiedyś z wolnym duchem humanistów? Nie pamiętam.

Nie mogę nie odnieść wrażenia, że czuwał nad nami wszystkimi ludźmi białostockiej filologii, szerzej całej humanistyki - dobry Duch, jakiś Bóg, który z tamtej wiosny '68 roku przyprowadził nas aż tutaj - w tę gorącą wiosnę roku 2018 ${ }^{12}$. I to pomimo tylu „przeciw”, „nie” i „nigdy”!

12 Osoby zainteresowane odsyłam do publikacji o dziejach uczelni: Białostockie środowisko filologiczne 1968-2018. Historia w 45 wywiadach, rozmawiał D. Sołowiej, idea i red. J. Ławski, Białystok 2018; Uniwersytet w Białymstoku in statu nascendi (1968-1997), wybór i opr. J. E. Dąbrowska, Białystok 2015; 10 lat Filii UW w Białymstoku. Miejsce uczelni uniwersyteckiej $w$ makroregionie pótnocno-wschodnim, red. J. Ledziński, Białystok 1978; Profesor Halina Krukowska. Doktor honoris causa Uniwersytetu w Biatymstoku, red. J. Godlewska, A. Janicka, J. Ławski, Białystok 2018; X lat Uniwersytetu w Białymstoku (1997-2007), red. J. Nikitorowicz et al., Białystok 2008 oraz Uniwersytet $w$ Biatymstoku: 2008-2017, red. R. Ciborowski et al., Białystok 2017. 
Że to się udało, jest zasługą wszystkich Państwa tu, we wspólnej Auli Wydziału Filologicznego i Wydziału Historyczno-Socjologicznego, zgromadzonych. Wszystkich Państwa, to jest Wspólnoty Uniwersyteckiej!

Wszystkim Państwu i tej Wspólnocie pojętej razem dziękuję. Dziękuję, życząc również przekornie optymistycznego spojrzenia w przyszłość...

(Któż oto wie z góry, co przynosi przyszłość...?)

Tradycja bowiem, którą zdobywaliśmy przez te lata, te pięćdziesiąt lat, mówi do nas: Spokojnie, „to” już było, już „to” przeżywaliśmy, przeżyjemy raz jeszcze!

Życzę Państwu tej nadziei wyrosłej z poznania i tworzenia tradycji uniwersyteckiej.

I przede wszystkim gratuluję. Gratuluję 50 lat!

Pół wieku... jak to szybko minęło! 


\section{ANEKS nr 2}

\section{Daniel Karczewski}

Prodziekan Wydziału Filologicznego ds. Nauki

\section{Szanowni Państwo,}

zwykle w tym miejscu stoję przed grupą około 100 studentów pierwszego roku anglistyki, którym staram się wyjaśniać na przykład główne założenia gramatyki generatywno-transformacyjnej Noama Chomskyego. Nie wychodzę poza moją strefę komfortu, ponieważ zazwyczaj jestem jedyną osobą z wszystkich obecnych na wykładzie, która słyszała o Chomskym i jego teoriach. Dzisiaj odczuwam pewien dyskomfort, stojąc przed grupą osób, która doskonale orientuje się w tematyce mojego wystąpienia. Pozostaje mi jedynie - podobnie jak na początku mojej przygody z dydaktyką uniwersytecką - poudawać, że wiem więcej niż w rzeczywistości.

Przejdźmy zatem do rzeczy...

Autorzy monografii pod tytułem Białostockie środowisko filologiczne: 1968-2018. Historia $w 45$ wywiadach, podają, że białostockie środowisko filologiczne powstało niemal z niczego. Dla porównania, biorąc pod uwagę jedynie pracowników naukowo-dydaktycznych zatrudnionych na Wydziale Filologicznym, obecne środowisko filologiczne tworzy: siedmiu profesorów tytularnych, trzydziestu dwóch profesorów nadzwyczajnych, trzydziestu dziewięciu adiunktów ze stopniem naukowym doktora, dwudziestu trzech asystentów, dziesięciu starszych wykładowców, czterech wykładowców oraz piętnastu lektorów (tj. około sto trzydzieści osób). Osób związanych w inny sposób z Wydziałem nie liczyłem. Wiem, że jest ich dużo, a może nawet bardzo dużo. Absolwentów Wydziału Filologicznego również nie policzyłem, ale jestem przekonany, że wykształciliśmy całe rzesze filologów różnej proweniencji.

Na tym moje dzisiejsze wyliczenia statystyczne prawie kończą się.

Mam wrażenie, że odetchnęli Państwo z ulgą.

Na tym mógłbym również zakończyć rys historyczny białostockiego środowiska filologicznego, lecz komitet organizacyjny jubileuszu powie- 
rzył mi zadanie ambitne - przedstawienie historii Wydziału Filologicznego (czy w zasadzie historii białostockiego środowiska filologicznego) w ciągu 10 minut. Mam więc jeszcze trochę czasu.

W cytowanej już dzisiaj monografii znajdziemy następującą periodyzację półwiecza białostockiego środowiska filologicznego:

„1968-1980 - pionierskie lata zawiązywania się środowiska, entuzjazmu edukacyjnego, zwieńczonego epoką >Solidarności<;

1981-1989 - epoka represji po stanie wojennym i stagnacji, czas podziałów w środowisku;

1990-2007 - czas przemian ustrojowych, edukacyjnych, naukowego wzmacniania się środowiska, uniezależniania;

2007-2015 - epoka kryzysu edukacji uniwersyteckiej (masowość studiów, obniżenie poziomu nauczania) przy równoczesnym kadrowym wzmocnieniu i awansie naukowym środowiska białostockiego;

po 2015 - czas kolejnych >reform<..."13

Jak zauważa Autor, taki podział pokazuje cechy wspólne ośrodka białostockiego z innymi ośrodkami humanistycznymi. Trudno się z takim podziałem kontinuum czasowego nie zgodzić. Tym bardziej, że Autorem tej periodyzacji jest sam Dziekan Wydziału Filologicznego, Pan Profesor Jarosław Ławski.

Ja z kolei, jako prodziekan ds. nauki oraz przede wszystkim językoznawca, chciałbym zaproponować Państwu spojrzenie na półwiecze białostockich filologów poprzez listę frekwencyjną wydobytą z korpusu 45 wywiadów przeprowadzonych przez Pana Dominika Sołowieja (absolwenta białostockiej polonistyki). Chciałbym zaznaczyć, że metodologia, którą zastosowałem w celu wyekscerpowania wyrazów o najwyższej frekwencyjności, nie nosi znamion pracy naukowej. Wszelkie próby replikowania moich badań mogą doprowadzić do stworzenia zupełnie innej listy.

Nie będę trzymał Państwa w napięciu i od razu przedstawiam wyniki mojego krótkiego badania. Oto moje top 10 (a w zasadzie top 7): WSN, filia, Świerkowa, Dom Partii, Wydział Filologiczny, kozy, konie i krowy, parametryzacja.

13 Białostockie środowisko filologiczne: 1968-2018. Historia w 45 wywiadach, rozmawiał D. Sołowiej, red. J. Ławski, Białystok 2018, s. 19-20. 
Zacznijmy od rozwinięcia pierwszego skrótu z mojej listy: WSN, czyli Wyższa Szkoła Nauczycielska. Powstała ona w wyniku restrukturyzacji I i II Seminarium Nauczycielskiego ${ }^{14}$, i należy w niej upatrywać początków naszego Wydziału. Wyższa Szkoła Nauczycielska działała jako trzyletnie studium zawodowe, składające się z trzech Wydziałów: Humanistycznego, Matematyczno-Przyrodniczego i Nauczania Początkowego ${ }^{15}$. WSN kształciło nauczycieli ,dla potrzeb szkolnictwa podstawowego i zasadniczych szkół zawodowych oraz prowadzenie prac naukowo-badawczych w zakresie dydaktyk szczegółowych"16. Dwoje z rozmówców Pana Redaktora Sołowieja to absolwenci WSN-u (Pani Doktor Bożena Chodźko oraz Pan Doktor Mikołaj Kruk). Absolwentami są również bardzo ważni członkowie mojej rodziny: teściowa Jadwiga oraz wuj Władysław. Teściowa, która ukończyła zarówno SN, jak i WSN, na studia magisterskie dostała się z polecenia Kuratorium. To Kuratorium - na podstawie ocen $\mathrm{w}$ indeksie i oceny z pracy dyplomowej - zdecydowało, że może ona kontynuować naukę na Uniwersytecie Warszawskim.

Pozycję numer dwa na mojej liście zajmuje Filia Uniwersytetu Warszawskiego działająca w Białymstoku od 15 lipca 1968 roku, najpierw pod nazwą Wyższa Szkoła Nauczycielska. Zajęcia prowadzili zarówno pracownicy Filii oraz pracownicy naukowo-dydaktyczni Uniwersytetu Warszawskiego. Zastępca rektora Uniwersytetu Warszawskiego ds. Filii w Białymstoku kierował pracą Filii. W roku 1978 na studiach dziennych i zaocznych kształciło się ponad 4600 studentów, z czego na Wydziale Humanistycznym $1111^{17}$.

Kolejne miejsce na mojej liście okupuje ulica Świerkowa - tutaj znajdowała się siedziba dawnego Wydziału Humanistycznego oraz Hotel Asystenta, w którym mieszkała część przyjeżdżających pracowników. W wyniku reformy ustrojowej Wydział Humanistyczny został przeniesiony do leżącego w centrum miasta Domu Partii (od roku 1993 wpisany do

14 X lat Uniwersytetu w Białymstoku (1997-2007), red. J. Nikitorowicz i in., Białystok 2008, s. 11.

15 Tamże, s. 11.

16 Tamże, s. 11.

17 Tamże, s. 11-12. 
Krajowego Rejestru Zabytków). Ponadto Wydział otrzymał wówczas budynek przy ulicy Liniarskiego 3 (dawna siedziba biblioteki KW PZPR) ${ }^{18}$. Wydziat Filologiczny - kolejne hasło z mojej listy - powstał w 1999 roku w wyniku podziału dawnego Wydziału Humanistycznego na Wydział Historyczno-Socjologiczny i Wydział Filologiczny. Obecnie w skład Wydziału wchodzą cztery instytuty: Instytut Filologii Polskiej, Instytut Filologii Wschodniosłowiańskiej, Instytut Neofilologii i najmłodszy, bo powołany w 2017 roku, Międzywydziałowy Instytut Kulturoznawstwa i Sztuki. Ponadto działają tu Zakład Kultury Białoruskiej oraz Zakład Hermeneutyki i Translatoryki Filozoficznej. W ramach Wydziału Filologicznego działa czternaście zespołów badawczych. Tego typu grupy robocze, zrzeszające pracowników oraz doktorantów i współpracowników spoza uczelni, były powołane w celu lepszej organizacji prac badawczych w ramach określonych tematów. Wydział posiada uprawnienia do nadawania stopnia doktora $w$ dyscyplinach językoznawstwo oraz literaturoznawstwo. Obecnie na wszystkich kierunkach studiów stacjonarnych oraz podyplomowych kształci się około 1200 studentów.

Na przedostatnim miejscu mojej listy znalazły się kozy, konie i krowy - nomina substantiva służące osobom związanym z Wydziałem Filologicznym do opisu krajobrazu Białegostoku circa 1950 roku.

Mimo bardzo niskiej frekwencyjności (słowo pojawiło się w korpusie dwa razy oraz dodatkowo dwa jego derywaty), parametryzacja czyli kompleksowa ocena jednostki zajmuje poczytne, ostatnie miejsce na mojej liście. Powodów tej decyzji jest kilka. Pierwszy (banalny) - ocena parametryczna spędzała mi sen z oczu przez ponad pół roku. Drugi (zdecydowanie ważniejszy) - to kategoria A przyznana Wydziałowi w efekcie oceny parametrycznej. Mam nadzieję, że zgodzą się Państwo, że był to najbardziej spektakularny sukces pracowników Wydziału Filologicznego w roku 2017.

Posiłkując się metaforą drogi, należy stwierdzić, że białostoccy filolodzy przeszli długą i wyboistą drogę - kozy i furmanki zniknęły z Białegostoku - a my nadal zajmujemy się tym, co niektórzy określają mianem zbędnej i anachronicznej formy intelektualnej aktywności. I oby nikt nam tego nie odebrał! 
Kończąc - bo jestem przekonany, że moje dziesięć minut już minęło - chciałbym życzyć wszystkim pracownikom Wydziału Filologicznego sukcesów naukowych, studentów, świadomie wybierających studia filologiczne oraz przemyślanych i skonsultowanych ze środowiskiem humanistycznym reform.

Chciałbym również podziękować naszym absolwentom, absolwentom Wydziału Filologicznego za liczne przybycie.

Szanowni Absolwenci, głęboko wierzę, że świat nie zwariuje do końca, a my, filolodzy, będziemy nadal potrzebni.

Dziękuję Państwu za uwagę.

Białystok, 9 września 2018 r. 